\title{
Anxiety and Depression are Two Important Causes of Erectile Dysfunction after Saturation Biopsy: A Pilot Study
} Satürasyon Biyopsisi Sonrası Ortaya Çıkan Erektil Disfonksiyonda Anksiyete
ve Depresyon İki Önemli Nedendir:Pilot Çalışma

\author{
Cem Akbal1, Polat Türker2, Çağrı A. Şekerci1', Mahir Bülent Özgen1, Ferruh Şimşek1, Levent Türkeri1 \\ 1 Marmara University Faculty of Medicine, Department of Urology, Istanbul, Turkey \\ 2 Namık Kemal University Faculty of Medicine, Department of Urology, Tekirdağ, Turkey
}

\begin{abstract}
What's known on the subject? and What does the study add?
Transrectal USG guided prostate biopsy is golden standard diagnostic modality for detecting prostate carcinoma. Although Zisman et al. reported that preoperative anxiety was in 64\% of biopsy events and anxiety peaked before result disclosure, there was acute erectile dysfunction in $9.7 \%$ of previously potent patients with low anxiety and without known etiology after standard 14-core biopsy. It is possible that ED may be caused by direct anatomical damage to neurovascular bundle or nerve compression due to the hematoma or edema (1). We retrospectively studied the impact of saturation prostate biopsy on the erectile function of patients whom have been detected prostate cancer related to anxiety factor. Here in this study, we used the objective validated questioners for all the evaluations. This study addresses the impact of anxiety factor on ED in patients with newly diagnosed prostate cancer.
\end{abstract}

\section{ABSTRACT}

\section{Objective}

To evaluate the role of the patient's mood as a possible cause of erectile dysfunction (ED) following transrectal ultrasound-guided saturation biopsy.

\section{Materials and Methods}

One hundred and thirty five patients who underwent a saturation biopsy due to persistently elevated levels of prostate specific antigen (PSA) were included in the study. Group 1 included 78 patients for whom the biopsy indicated that they were cancer-free, and group 2 included 57 patients for whom the biopsy indicated that they had prostate cancer and were thus on a waiting list for a radical treatment. Patients were evaluated using the International Index of Erectile Function-5 (IIEF-5) and the Hospital Anxiety-Depression Scale (HADS).

\section{Results}

Among the cancer-free group, 17\% of patients exhibited a decline in erectile function after the biopsy according to their IIEF- 5 scores. The anxiety or depression rate according to the HADS was $69 \%$ in the patients exhibiting a decrease in erectile function, which was greater than that of the rest of the cancer-free patients who had no erectile function deterioration. Patients who learned that they had cancer exhibited a statistically significant average decrease in IIEF-5 scores ( $p=0.04)$. Their scores on the HADS were significantly higher.

\section{Conclusion}

Although a saturation biopsy of the prostate is a safe procedure in terms of erectile function, the risk of ED after a biopsy should be discussed with patients who have had previous normal erectile function and have been diagnosed with cancer.

\section{Key Words}

Erectile dysfunction, saturation biopsy, prostate cancer, anxiety, depression

\section{ÖZET}

Amaç

Transrektal prostat satürasyon biyopsisi sonrası ortaya çıkan erektil disfonksiyona hastaların ruh hallerinin etkisi araştırıldı.

\section{Gereç ve Yöntem}

PSA yüksekliği nedeniyle satürasyon biyopsisi uygulanan 135 olgu çalışmaya dahil edildi. Grup 1; 78 cinsel olarak aktif ve biyopsi sonucu negatif gelen olgudan oluşurken, grup 2; cinsel olarak aktif biyopsi sonucu kanser olan ve radikal cerrahi bekleyen 57 olgudan oluşuyordu. Olgular uluslararası erektil fonksiyon indeksinin 5 soruluk (IIEF-5) Formu ve Hastawne Anksiyete Depresyon Skalası ile değerlendirildiler.

\section{Bulgular}

Grup 1'de \%17 olgu biyopsi sonrası erektil disfonksiyon tarifliyordu ve bunların hastane anksiyete depresyon skalasına göre \%69 pozitiflik mevcutdu $(p=0,0003)$. Kanser olduğunu öğrenen olgularda da IIEF-5 skoru biyopsi sonrası azalmıştı. Bu olgularda da hastane anksiyete depresyon skalası yüksekti $(p=0.04)$.

\section{Sonuç}

Prostat saturasyon biyopsisi erektil fonksiyon üzerine etkisi olmayan bir invaziv girişim olsada hastalara geçici erektil disfonksiyon açısından bilgi verilmelidir. Bu etki biyopsi sonrası kanser saptanan olgularda daha yüksektir.

\section{Anahtar Kelimeler}

Erektil disfonksiyon, satürasyon biyopsisi, prostat kanseri, depresyon

\section{Correspondence}

Cem Akbal MD, Marmara University Faculty of Medicine, Department of Urology, İstanbul, Turkey

E-mail:cakbal@gmail.com

Journal of Urological Surgery. 


\section{Introduction}

Following skin cancer, prostate cancer ( $\mathrm{PCa}$ ) is the second most commonly diagnosed cancer in America. The latest American Cancer Society estimates for prostate cancer suggest that about 233.000 new cases of PCa will be diagnosed; additionally, 29.480 men died due to PCa in 2014. Nevertheless, more than 2 million men in the United States who have been diagnosed with PCa at some point in their lives are still alive today. PCa accounts for about 10\% of cancer-related deaths (1). In order to increase the chance of an early diagnosis, the cut off point for the level of Prostate Specific Antigen (PSA) to trigger a biopsy has been decreased, and the standard number of core samples taken from a transrectal ultrasound guided biopsy, which is the golden standard diagnostic tool for PCa, has been increased (2).

Erectile dysfunction (ED) is defined as the inability to develop and maintain an erection in order to engage in satisfactory sexual intercourse. An evaluation of erectile dysfunction can be achieved by using the International Index of Erectile Function-5 (IIEF-5), i. e., a 5 -item questionnaire that has been developed and validated as a brief and reliable self-administered scale $(3,4,5)$. Patients who underwent prostate biopsies may report ED due to the possible effects from the acute healing phase in the prostate after the procedure and anxiety related to a possible cancer diagnosis. In our previous study, patients who previously had normal erectile function and were found to be free of prostate cancer exhibited ED rates of $11.6 \%$ during the first month after the biopsy (6). In Zisman's study, the frequency of acute ED after biopsy was reported to be $9.7 \%$, and the authors speculated that perineural edema, hematoma, and the anxiety from the possibility of having cancer were responsible (7). Zisman observed as high as 64\% frequency of anxiety during the work up for the diagnosis of cancer, which reaches its maximum at the time of the announcement of the biopsy result (7). The anxiety over the possibility of having PCa might be a potential factor that affects post biopsy erectile function.

Herein, we designed a prospective study to evaluate the patient's erectile function and psychological mood before the saturation biopsy and after the announcement of the biopsy results to evaluate the effect of anxiety on erectile function in these patients.

\section{Materials and Methods}

One hundred and thirty five patients who underwent a saturation biopsy due to persistently elevated prostate specific antigen (PSA) levels were included in the study. Before the biopsy procedure, all of the subjects were asked to complete the IIEF-5 questionnaire and the Hospital Anxiety-Depression Scale (HADS) scale when they were unaware of the results of the biopsy. After the delivery of the biopsy report, patients were divided in two groups, i. e., those who had and those who did not have PCa. Group 1 included 78 patients who were cancer free based on the biopsy result, and group 2 included 57 patients who were diagnosed with PCa after the biopsy and scheduled for radical treatment. Both groups of patients also completed the IIEF-5 questionnaire and HADS scale one month after they learned their individual biopsy result.

Biopsy Procedure: Considering the prostatic longitudinal axis, a median of 24 (min:20-max:30) core prostate saturation biopsies were taken. Biopsy specimens were collected under general anesthesia using TRUS guidance (6). The volume of the prostate gland was calculated using the ellipsoid formula (Volume in $\mathrm{ml}=0.524 \times$ [length $x$ height $x$ width]).

IIEF-5 Questionnaires: The IIEF-5 is designed to detect the presence and severity of ED. Patients can self assess their ED using the IIEF-5, and their assessment usually represents performance over the past three months (5). The range of possible IIEF- 5 scores is between 5 and 25. We classified the severity of ED into the following four categories based on the obtained IIEF-5 scores: severe (5-7), moderate (8-16), mild (17-21), and no ED (22-25). All patients were asked to complete the validated version of the IIEF-5 questionnaire (8) before the biopsy and 1 month after the biopsy report.

\section{Hospital Anxiety and Depression Scale}

The HADS is a self-assessment scale that is considered a reliable instrument for detecting states of depression and anxiety for patients in a hospital/medical outpatient clinic (9). The anxiety and depressive subscales are also valid measures of the severity of an emotional disorder. Reportedly, the introduction of the use of this assessment into general hospital practices would facilitate the detection and management of emotional disorders for patients who are under investigation and treatment within medical and surgical departments. The anxiety and depression scales within the HADS both include seven questions that patients answer by providing a rating from a score of 0 to 3 depending on the severity of the problem described in each question. The two sub-scales can also be aggregated to provide an overall anxiety and depression score.

According to the validated Turkish HADS, the cut-off points for the anxiety sub-scales and the depression sub-scales are 10 and 7, respectively $(9,10)$. Participants completed the HADS along with the IIEF-5 such that we could assess their current psychological state.

Statistics: A chi square analysis was used to compare erectile function according to the IIEF-5 for both groups before and after the biopsy procedure and also to compare the anxiety or depression in both positive and negative patients. Graph Pad Instat and SPSS 21.0 computer programs were used to complete the statistical analyses, and $p<0.05$ value was accepted as statistically significant.

\section{Results}

The demographic characteristics of the participating patients are shown in Table 1. Indications that triggered the biopsies for both groups were as follows: a PSA value higher than $2.5 \mathrm{ng} / \mathrm{ml}$ with a normal digital rectal examination (DRE) for 125 patients, an abnormal DRE with a normal PSA value for three patients, and both an abnormal DRE and high PSA levels for eleven patients.

The change in the IIEF-5 scores after the biopsies showed no correlation with the patients' ages, serum PSA levels, prostate volumes, and number of cores.

The saturation biopsy was the initial biopsy for 42 patients. In contrast, 88 patients had previously undergone one biopsy, and 5 patients had previously undergone two biopsies.

\section{Patients Who Reported to be Cancer-Free (Group 1):}

The number of patients who were found to be cancer-free based on the biopsy was 78. In this group, the ED rate before the biopsy 
was $58 \%(n=45)$, and the ED rate was $64 \%(n=50) 1$ month after the biopsy report.

Among these 78 patients, the frequency of anxiety or depression was $35 \%(n=27)$ before the biopsy and 24\% $(n=19) 1$ month after the biopsy report according to their scores on the HADS scale.

Although no statistically significant difference was observed between the pre-biopsy and post-biopsy IIEF-5 scores (Table 2), 13 patients $(17 \%)$ exhibited a decline in their IIEF-5 classifications (i. e., 3 patients

Table 1. Patient characteristics of the study groups

\begin{tabular}{|c|c|c|}
\hline & Group $1(n=78)$ & Group $2(n=57)$ \\
\hline \multicolumn{3}{|l|}{ Age } \\
\hline Mean $+/$ SD & $61.8+\mid-6.7$ & $65.7+/-7.5$ \\
\hline Median (range) & $61(42-77)$ & $65(46-80)$ \\
\hline \multicolumn{3}{|l|}{ Serum PSA } \\
\hline Mean +/-SD & $8.0+/-3.8$ & $10.7+/-9.1$ \\
\hline Median (range) & $7.2(1.2-28.9)$ & $8(1.5-43)$ \\
\hline \multicolumn{3}{|l|}{ Prostate Vol. (ml): } \\
\hline Mean +/- SD & $55+/-23$ & $43.1+/-10.2$ \\
\hline Median (range) & $55(18-162)$ & $40(14-68)$ \\
\hline \multicolumn{3}{|l|}{ No of cores } \\
\hline Mean +/-SD & $26.04+/-1.7$ & $25.4+/-1.5$ \\
\hline Median (range) & $26(20-30)$ & $26(20-26)$ \\
\hline \multicolumn{3}{|l|}{ Preop IIEF-5 scores } \\
\hline Mean +/- SD & $19+\mid-5.1$ & $18+/-5.7$ \\
\hline Median (range) & $20(6-25)$ & $20(5-25)$ \\
\hline
\end{tabular}

Table 2. Comparison of erectile function according to IIEF-5 groups before and after the biopsy procedure in BPH patients

\begin{tabular}{|l|l|l|l|}
\cline { 1 - 2 } $\begin{array}{l}\text { Erectile function } \\
\text { according to IIEF-5 } \\
\text { score }\end{array}$ & Pre biopsy & $\begin{array}{l}\text { Postbiopsy } \\
1^{\text {st }} \text { month }\end{array}$ & $p$ (chi-square) \\
\cline { 1 - 3 } No ED (22-25) & $33(42 \%)$ & $28(36 \%)$ & \multirow{2}{*}{0.2} \\
\cline { 1 - 3 } Mild Ed (17-21) & $22(28 \%)$ & $20(26 \%)$ & \\
\cline { 1 - 3 } Moderate ED (8-16) & $20(26 \%)$ & $24(31 \%)$ & \\
\cline { 1 - 3 } Severe ED (5-7) & $3(4 \%)$ & $6(8 \%)$ & \\
\hline
\end{tabular}

moved from no ED to the mild ED group, and 2 moved from no ED to the moderate ED group; 5 patients moved from mild ED to the moderate ED group, and 3 patients moved from moderate ED to the severe ED group) at one month after receiving the biopsy result.

To determine the effect of anxiety or depression on this deterioration of erectile function, if any, we compared the rate of anxiety or depression among these 13 patients who exhibited a decline in IIEF5 group to that of patients who experienced no decline in erectile function $(n=65)$ (Table 3$)$. The anxiety or depression rate was 69\% $(n=9)$ among the group with a decline in erectile function and only $17 \%(n=11)$ among the rest according to the HADS scores ( $p=0.0003)$.

\section{Patients Who were Diagnosed with Prostate Cancer (Group 2):}

The number of patients who were diagnosed with prostate cancer based on the biopsy was 57 . ED rates were $70 \%(n=40)$ and $84 \%$ $(\mathrm{n}=48)$ before and after the biopsy, respectively.

Among these patients, the anxiety or depression frequency before biopsy was 25\% $(n=14)$, and 1 month after receiving the biopsy report that indicated a positive diagnosis of prostate cancer, the anxiety or depression frequency was $98 \%(n=56)$.

A statistically significant decrease was observed in the IIEF-5 scores for these patients ( $p=0.04$, Table 4). Eighteen subjects (32\%) exhibited a decrease in their IIEF-5 classification (i. e., 5 patients moved from no ED to the mild ED group, and 4 moved from no ED to the moderate ED group; 5 patients moved from mild ED to the moderate ED group, and 1 patient moved from mild to the severe ED group; 3 patients moved from moderate ED to the severe ED group).

According to their scores on the HADS, which patients completed one month after they received the biopsy report, all 18 patients had anxiety or depression. Moreover, $70 \%(n=28)$ of the remaining cancer positive patients $(n=39)$ who showed no decrease in erectile function during the post biopsy period demonstrated anxiety or depression according to their HADS scores ( $p=0.028$, Table 5 ).

\section{Concomitant Diseases and Post Biopsy Erectile Dysfunction}

Of the 78 patients in group 1, 13 patients indicated that they experienced deterioration in erectile function according to their IIEF-5 classification at one month after receiving the biopsy report. Among these thirteen patients, the following concomitant diseases were present:

Table 3. Comparison of erectile function according to IIEF-5 score before and after the biopsy procedure in BPH patients who had and had no anxiety or depression according to HADS scale (cut off point for anxiety and depression are 10 and 7 respectively)

\begin{tabular}{|l|l|l|l|}
\hline & Worse after biopsy according to IIEF-5 & The same or better according to IIEF-5 & $p$ (chi-square) \\
\hline Anxiety or depression positive & $9(69 \%)$ & $11(17 \%)$ & 0.0003 \\
\hline Anxiety or depression negative & $4(31 \%)$ & $54(83 \%)$ & 65 \\
\hline Total & 13 & & \\
\hline
\end{tabular}

Table 4. Comparison of erectile function according to IIEF-5 groups before and after the biopsy procedure in Prostate Cancer patients

\begin{tabular}{|l|l|l|l|}
\hline Erectile function according to IIEF-5 score & Pre biopsy & Postbiopsy 1st month & $p$ (chi-square) \\
\hline No ED (22-25) & $17(30 \%)$ & $9(16 \%)$ & 0.04 \\
\hline Mild ED (17-21) & $20(35 \%)$ & $19(33 \%)$ \\
\hline Moderate ED (8-16) & $15(26 \%)$ & $20(35 \%)$ \\
\hline Severe ED (5-7) & $5(9 \%)$ & $9(16 \%)$ \\
\hline
\end{tabular}


Table 5. Comparison of erectile function according to IIEF-5 score after the biopsy procedure in Prostate Cancer patients who had and had no anxiety or depression according to HADS scale (cut off point for anxiety and depression are 10 and 7 respectively)

\begin{tabular}{|l|l|l|l|} 
& Worse after biopsy according to IIEF-5 & The same or better according to IIEF-5 & $p$ (chi-square) \\
\hline Anxiety or depression positive & $18(100 \%)$ & $28(72 \%)$ & \multirow{2}{*}{0.03} \\
\hline Anxiety or depression negative & 0 & $11(28 \%)$ & \\
\hline Total & 18 & 39 & \\
\hline
\end{tabular}

- Four patients had hypertension and diabetes mellitus (DM) type 2 and were thus using oral antidiabetics,

- Six of them had only hypertension; and,

- The remaining 3 patients had no concomitant disease.

In group 2, 18 patients out of 57 experienced a decline in IIEF-5 classification after they received the biopsy report. Of these eighteen patients, the following concomitant diseases were present:

- Fourteen had hypertension,

- Eight had coronary heart disease,

- Eight had hyperlipidemia; and,

- Two had DM type 2 and were thus using oral anti-diabetics.

\section{Discussion}

Recent studies have shown that carcinoma of the prostate could be detected by PSA values that were previously accepted as normal and an increase in the number of biopsy core samples, thereby creating the standard saturation biopsy protocols used today (11). An increase in the number of collected core samples gave rise to better cancer detection. Waltz reported a $41 \%$ increase in cancer detection rate with saturation biopsy when compared to previously traditional 10 core biopsies (12). Another study suggested that the increase in the number of core samples was not correlated with an increase in complication rate (13). The increase in cancer detection rates also improved the possibility of detecting clinically unimportant cancers, which increased to $15.6 \%$ with the use of the saturation biopsy protocols $(11,12,13)$.

Our previous report indicated that according to the IIEF-5 scores, patients who had previously normal erectile function and were found to be free of prostate cancer had ED rates of $11.6 \%$ in the first month, and no ED was reported in the sixth month of evaluation (6). In Zisman's study, patients who previously had normal erectile function and had 14 core biopsies and low anxiety scores reportedly demonstrated $9.7 \%$ acute ED (6). In these two studies, the pathology reports were not evaluated (7). Korfage's study showed that $28 \%$ of PCa patients had high anxiety levels before treatment (14). Garos et al. also reported that PCa patients and their partners differed in terms of their sexual self-esteem, sexual depression, sexual preoccupation, and life satisfaction as compared to the general population. Specifically, both reported greater levels of depression, poorer quality of sexual communication, and more sexual dissatisfaction than the general population (15). According to our present study, the impact of the saturation prostate biopsy protocol on erectile function affected both cancer patients and cancer free patients, thereby indicating increased anxiety due to the possible presence of a potentially lethal disease resulted in ED, thus having a profound effect on erectile function. In contrast to previous studies, the patients in our study who underwent prostate saturation biopsy that indicated the presence of PCa reported 60\% ED in the first month after the biopsy $(6,7)$.

Although the degree of ED one month after the biopsy seems to be statistically significant with respect to the scores on the IIEF5 for the cancer free group, the thirteen patients who reported no ED before the biopsy reported new onset ED after the biopsy and then returned to baseline at 6 months after the biopsy. An improvement in erectile function was observed in some patients $(n=6)$ with a maximum increase of 3 points in the IIEF-5 score. This improvement might be due to decreased anxiety stemming from the possible presence of a potentially lethal disease after they received a negative biopsy result.

According to our study population, the patients in group 2 were older than group 1 and reported to have more concomitant disease than group 1 patients. The Massachusetts Male Aging Study (16) revealed that ED is an age-dependent disorder; i. e., "Between the ages of 4070 years, the probability of complete impotence tripled from 5.1\% to $15 \%$, moderate impotence doubled from $17 \%$ to $34 \%$, while the probability of minimal impotence remained constant at 17\%". After the data was adjusted for age, the men who were being treated for diabetes (28\%), heart disease (39\%), and hypertension (15\%) had significantly higher probabilities for ED than the sample as a whole (9.6\%). Although many patients did not report any progression of concomitant disease after biopsy, those diseases may affect erectile function in prostate cancer patients.

The sexual rehabilitation for patients with a positive result from a prostate biopsy would be beneficial to the PCa patient's sexual life. According to the study from MD Anderson Cancer Centre, couples randomly assigned to attend four sessions of counseling either together or alone (i. e., only the patient attended). The sessions included education about prostate carcinoma, sexual function, and options to treat ED, sexual communication, and sexual stimulation skills. In both groups, partners completed behavioral homework. As a result of sexually counseling, patients demonstrated significant gains in sexual function and satisfaction and increased utilization of treatments for ED (17).

In our study, one of the leading causes of ED in group 2 was depression and anxiety as confirmed by the HADS assessment. Zisman observed as high as 64\% frequency of anxiety during the work up for the diagnosis of cancer, and this anxiety reaches its maximum at the time of the announcement of the biopsy result (7). Norton et al. not only reported a negative association between anxiety and sexual dysfunction but also addressed the effectiveness of anxiety reducing procedures for the treatment of sexual dysfunctions (15). The anxiety associated with the probability of having PCa would be a potential factor that would affect post biopsy erectile function. 


\section{Conclusion}

Our study was designed to evaluate the effect of prostate saturation biopsy, which is used for the diagnosis of $\mathrm{PCa}$, on erectile function. Our results indicated that in the early post biopsy period, transient ED can be observed as a result of anxiety and depression even in subjects who previously had normal erectile function. The impact of the biopsy on sexual function would be more prominent in patients who have been newly diagnosed with $\mathrm{PCa}$ due to the negative contribution of the anxiety or depression on sexual function. The patients should attend counseling either together with their partner or alone to seek treatment for anxiety and depression. Although the saturation biopsy of the prostate is a safe procedure in terms of erectile function, the risk for ED after the biopsy should be discussed with patients with previously normal erectile function.

\section{Conflicts of Interest}

There are no conflicts of interest.

\section{References}

1. http://www.cancer.org/docroot/CRI/content

2. Boccon-Gibod LM, de Longchamps NB, Toublanc M, Boccon-Gibod LA, Ravery V. Prostate saturation biopsy in the reevaluation of microfocal prostate cancer. J Urol 2006;176:961-963.

3. Wespes E, Amar E, Hatzichristou DG, Montorsi F, Pryor J, Vardi Y. EAU guidelines on erectile dysfunction. Eur Urol 2002;41:1-5.

4. Kassouf W, Carrier S. A comparison of the International Index of Erectile Function and erectile dysfunction studies. BJU Int 2003;91:667-669.

5. Rosen RC, Cappelleri JC, Smith MD, Lipsky J, Pena BM. Development and evaluation of an abridged, 5-item version of the International Index of Erectile Function (IIEF-5) as a diagnostic tool for erectile function. Int J Impot Res 1999;11:319-326.

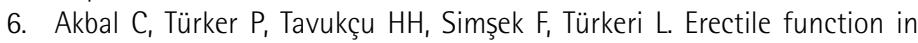
prostate cancer-free patients who underwent prostate saturation biopsy. Eur Urol 2008;53:540-544.
7. Zisman A, Leibovici D, Kleinmann J, Siegel YI, Lindner A. The impact of prostate biopsy on patient well-being: a prospective study of pain, anxiety and erectile dysfunction. J Urol 2001;165:445-454.

8. Turunç T, Deveci S, Güvel S, Peşkirçioğlu L. The Assessment Of Turkish Validation With 5 Question Version Of International Index Of Erectile Function (IIEF-5) Turkish Journal of Urology 2007:33:45-49.

9. Zigmond AS, Snaith RP. The hospital anxiety and depression scale. Acta Psychiatr Scand 1983;67:361-370.

10. Aydemir Ö, Güvenir T, Küey $L$, et al: Validation of Turkish Version of Hospital Anxiety and Depression Scale. Turkish Journal of Psychiatry 1997;8:280-287.

11. Amling CL. Prostate-specific antigen and detection of prostate cancer: What have we learned and what should we recommend for screening? Curr Treat Options Oncol 2006;7:337-345.

12. Walz J, Graefen M, Chun FK, Erbersdobler A, Haese A, Steuber T, Schlomm T, Huland $\mathrm{H}$, Karakiewicz PI. High incidence of prostate cancer detected by saturation biopsy after previous negative biopsy series. Eur Urol 2006;50:498-505.

13. Jones JS, Patel A, Schoenfield L, Rabets JC, Zippe CD, Magi-Galluzzi C. Saturation technique does not improve cancer detection as an initial prostate biopsy strategy. J Urol 2006;175:485-488.

14. Singh $H_{1}$ Canto El, Shariat SF, Kadmon D, Miles BJ, Wheeler TM, Slawin KM. Improved detection of clinically significant, curable prostate cancer with systematic 12-core biopsy. J Urol 2004;171:1089-1092.

15. Korfage IJ, Essink-Bot ML, Janssens AC, Schroder FH, de Koning HJ. Anxiety and depression after prostate cancer diagnosis and treatment: 5-year follow-up. Br J Cancer 2006;94:1093-1098.

16. Garos S, Kluck A, Aronoff D. Prostate cancer patients and their partners: differences in satisfaction indices and psychological variables. J. Sex Med 2007;4:1394-1403.

17. Feldman HA, Goldstein I, Hatzichristou DG, Krane RJ, McKinlay JB. Impotence and its medical and psychosocial correlates: results of the Massachusetts Male Aging Study. J Urol 1994;151:54-61.

18. Canada $A L$, Neese $L E$, Sui $D$, Schover LR. Pilot intervention to enhance sexual rehabilitation for couples after treatment for localized prostate carcinoma. Cancer 2005;104:2689-2700. 